\title{
KAJIAN TENTANG PENDIDIKAN KARAKTER PADA SEKOLAH RAMAH ANAK UNTUK SISWA KELAS V
}

\author{
Laelatus Saadah ${ }^{1}$, Didik Tri Setiyoko ${ }^{2}$, Atikah Mumpuni ${ }^{3}$ \\ ${ }^{123}$ Program Studi PGSD Universitas Muhadi Setiabudi \\ Email: atikahmumpuni@umus.ac.id
}

\begin{abstract}
Character education is education that must be applied to children as early as possible to prevent deviant behavior such as bullying, the problem statement in this study is the pattern of character education learning so that children avoid bullying cases and supporting factors in character education learning patterns so that children avoid bullying in school programs child friendly. The methodology in this study uses descriptive qualitative research methodology with the approach used is the phenomenology approach. The data collection technique uses the method of observation, interviews, and documentation. The results of this study illustrate that the pattern of learning character education so that children avoid Bullying cases is by doing positive habituation. Supporting factors in Klampok 01 Elementary School towards the success of the school are exemplary attitudes applied by all educators, especially principals about good habituation in schools that must be supported by all school equipment, both teacher / principal, school principals, staff and school guards . In this study it can be concluded that the pattern of character education and supporting factors for children to avoid Bullying cases is by way of positive habituation and exemplary that must be applied by all school members. In this case the role of the teacher in developing learning strategies Character education must be supported by all citizens, both school citizens and community members.
\end{abstract}

\section{Keywords: Character Education, Child-Friendly School}

\begin{abstract}
Abstrak. Pendidikan karakter merupakan pendidikan yang harus diterapkan pada anak sedini mungkin untuk mencegah adanya perilaku menyimpang seperti Bullying, rumusan masalah dalam penelitian ini adalah pola pembelajaran pendidikan karakter agar anak terhindar dari kasus bullying dan faktor pendukung pola pembelajaran pendidikan karakter agar anak terhindar dari bullying pada program sekolah ramah anak. Metodologi dalam penelitian ini menggunakan metodologi penelitian kualitatif deskriptif dengan pendekatan yang di gunakan yaitu pendekatan fenomenologi. Teknik pengumpulan datanya menggunakan metode observasi, wawancara, dan dokumentasi. Hasil penelitian ini menggambarkan bahwa pola pembelajaran pendidikan karakter agar anak terhindar dari kasus Bullying yaitu dengan cara melakukan pembiasaan positif. Faktor pendukung di SD Negeri Klampok 01 terhadap keberhasilan sekolah yaitu sikap keteladanan yang diterapkan oleh seluruh tenaga pendidik terutama kepala sekolah tentang pembiasaan yang baik dalam sekolah yang harus di dukung oleh seluruh perangkat sekolah, baik bapak/ibu guru, kepala sekolah, staf maupun penjaga sekolah. Pada penelitian ini dapat disimpulkan bahwa pola pendidikan karakter dan faktor pendukung agar anak terhindar dari kasus Bullying yaitu dengan cara pembiasaan yang positif dan keteladanan yang harus diterapkan oleh seluruh
\end{abstract}


warga sekolah. Dalam hal ini peranan guru dalam mengembangkan strategi pembelajaran Pendidikan karakter harus di dukung oleh semua warga, baik warga sekolah maupun warga masyarakat.

Kata Kunci: Pendidikan Karakter, Sekolah Ramah Anak

Pendidikan di Indonesia terbagi ke dalam tiga jalur utama, yaitu salah satunya formal (Sekolah), Pendidikan yang didapatkan dari sekolah tidak hanya tentang materi pelajaran, disekolah para siswa di ajarkan tentang bagaimana mereka bertindak, bertingkah laku adanya sikap saling menghormati, menghargai, dan menyayangi. Dengan adanya pengaplikasian tentang bertingkah laku yaitu adanya saling menghormati, menghargai, dan menyayangi, para pendidik berharap agar para siswa dijauhkan dari adanya tindak kekerasan baik di lingkungan sekolah maupun lingkungan luar sekolah. Namun pada kenyataannya sering terjadi akhir-akhir ini yaitu tentang kasus bully terhadap sesama siswa.

Menurut

Kementerian

pemberdayaan perempuan dan perlindungan anak Republik Indonesia (2015: 9), bahwa Data KPAI (2014-2015) tentang Kasus Kekerasan (Kekerasan Fisik, Psikis, Seksual dan Penelantaran Terhadap Anak), sebanyak 10\% dilakukan oleh guru. Bentuk- bentuk kekerasan yang banyak ditemukan berupa pelecehan (bullying), serta bentuk- bentuk hukuman yang tidak mendidik bagi peserta didik, seperti mencubit (504 kasus), membentak dengan suara keras (357 kasus) dan menjewer (379 kasus), Data KPAI 2013.
Tahun 2017 kasus bullying sempat menjadi viral di media sosial terkait perundungan yang dilakukan oleh beberapa siswi di Jakarta, melihat dari video yang tersebar, dinas pendidikan DKI Jakarta merespon cepat terkait video aksi perundungan atau Bullying sekelmopok remaja dilorong pusat perbelanjaan mall Thamrin City, Jakarta. yang melibatkan Dua pelajar yaitu siswi SD dan siswi SMP, dimana siswi yang memakai seragai putih biru menjambak korban sampai korban terjatuh, dan tidak hanya itu di video yang sempat menjadi viral di medsos ini terlihat bahwa korban sampai dipaksa untuk mencium kaki siswi SMP, Kasus ini melibatkan lebih dari 9 orang.

Bullying atau perundungan terhadap siswi kelas enam SD oleh sembilan pelajar berlangsung di lorong lantai 3A Thamrin City, pada Jumat 14 Juli 2017.Perundungan yang melibatkan pelajar SMP dan SD di pusat perbelanjaan, ikut menyedot perhatian Gubernur Jakarta Djarot Saiful Hidayat. Selain mengecam, Djarot menilai para pelaku akan di kembalikan kepada orangtua, sekaligus pencabutan Kartu Jakarta Pintar (KJP). Djarot juga memerintahkan kepala Dinas Pendidikan Jakarta untuk melakukan investigasi (Liputan6, 2017)

Melihat konteks tersebut, terlihat sangat miris pendidikan di Indonesia, yang pelakunya masih dibawah umur, tentu dengan adanya hal tersebut perlu 
upaya dari pemerintah untuk mengurangi adanya hal tersebut terulang kembali yaitu kasus bully pada anak. Adapun kasus yang baru saja mencoreng pendidikan di Indonesia yaitu dengan meninggalnya guru Budi di sampang Madura, beliau meninggal di duga karena adanya penganiayaan yang dilakukan oleh muridnya saat kegiatan belajar mengajar berlangsung.

Kondisi yang telah dipaparkan memerlukan pemecahan yang fundamental dan komprehensif.

Menurut Daryanto \& Darmiatun (2013:64) bahwa pendidikan karakter yaitu merupakan usaha yang dlakukan oleh para personil sekolah, bahkan yang dilakukan bersama-sama dengan orang tua dan anggota masyarakat, untuk membantu anak-anak dan remaja agar menjadi atau memiliki sifat peduli, berpendirian dan bertanggung jawab.

Pendidikan ramah anak yang diterapkan di sekolah baik secara langsung maupun tidak langsung bertujuan agar terbentuknya karakter yang baik bagi diri siswa. Pendidikan karakter tidak saja merupakan tuntutan undang-undang dan peraturan pemerintah, tetapi juga oleh agama.

Sekolah harus menciptakan suasana yang kondusif agar anak merasa nyaman dan dapat mengekspresikan potensinya, pada hakikatnya program sekolah ramah anak merupakan sekolah yang menciptakan kondisi aman, ramah, dan menyenangkan bagi siswa sehingga siswa lebih konsentrasi dalam belajar.

Maka dari itu penulis tertarik untuk melakukan penelitian di SD Negeri Klampok 01 dengan judul : “Kajian tentang Pendidikan Karakter pada
Sekolah Ramah Anak untuk Siswa kelas V (Studi Kasus SD Negeri Klampok 01)"

\section{METODE}

Penelitian dilaksanakan di SDN Klampok 01, Kecamatan Wanasari, Kabupaten Brebes. Subjek penelitian adalah siswa kelas $\mathrm{V}$ tahun ajaran 2018/2019 dengan fokus penelitian bagaimana pendidikan karakter agar anak terhindar dari kasus kekerasan atau bullying pada Sekolah Ramah Anak di SD Negeri Klampok 01. Teknik pengumpulan data dalam penelitian ini dengan melakukan wawancara melalui lembar wawancara kepada informan antara lain, Kepala Sekolah, Guru dan Siswa kelas V. Melakukan observasi melalui lembar observasi lingkungan dengan aspek yang diamati berupa lingkungan sekolah, kantor, kelas, UKS, mushola, kamar mandi (WC), perpustakaan dan kantin serta observasi kelas dengan aspek yang di amati tentang kelas mendukung atau tidak dalam pendidikan karakter dan pengintegrasian pendidikan karakter dalam pembelajaran, semua aspek yang di amati bertujuan agar peneliti mengetahui tentang pendidikan karakter agar anak terhindar dari kasus bullying. Peneliti menggunakan teori interaksi simbolik dari george herbert mead berfokus pada "self concept" yaitu tentang I and Me.

\section{HASIL DAN PEMBAHASAN}

\section{A. Hasil Penelitian}

Bertolak dari rumusan masalah yang di munculkan oleh peneliti dengan metode observasi, wawancara dan dokumentasi. Hasil wawancara merupakan hasil yang diperoleh melalui 
wawancara dengan informan atau narasumber, informan dalam penelitian ini adalah Kepala Sekolah, Guru kelas V, Guru kelas III dan siswa siswi kelas V.

Pola Pembelajaran Pendidikan Karakter Agar Anak Terhindar dari Kasus Kekerasan atau Bullying pada Siswa Kelas V Di SD Negeri Klampok 01

Berdasarkan pada hasil penelitan dan observasi di SD Negeri Klampok 01 merupakan sekolah ramah anak yang didalamnya menerapkan pendidikan karakter, setiap warga sekolah berperan dalam pembentukan karakter bagi diri siswa. Pola pendidikan karakter yang di dapatkan seluruh siswa di SD Negeri Klampok 01 diawali dengan siswa yang baru datang akan disambut oleh bapak/ibu guru di depan gerbang sekolah untuk 3S (Senyum, Salam, dan Sapa). Saat bel pertama (5 menit) sebelum pelajaran dimulai siswa dibiasakn untuk berbaris di depan kelas masing-masing, dengan salah satu diantaranya mengetuai untuk berbaris rapi.

Faktor Pendukung Pola Pembelajaran Pendidikan Karakter Agar Anak Terhindar Dari Kasus Kekerasan Atau Bullying Pada Program Sekolah Ramah Anak Siswa Kelas V di SD Negeri Klampok 01

Salah satu faktor pendukung pola pembelajaran pendidikan karakter di SD Negeri Klampok 01 adalah adanya penerapan teladan yang baik dari Kepala Sekolah SD Negeri Klampok 01.

Hal ini sesuai dengan yang di ungkapkan oleh Ibu Sopiyah (wawancara, Agustus 2018) “... melalui sikap contoh keteladanan, jadi misalkan membuang sampah...". beliau juga menyampaikan faktor pendukung pendidikan karakter yang lain dengan adanya kesadaran dari seluruh warga sekolah “....mulai dari kesadaran keseluruhan warga sekolah terutama, yaa semua menyadari akan pendidikan karakter untuk membentuk siswa menghadapi sekian tahun kedepan kan tujuannya untuk itu, kemitraan juga mendukung seperti kepolisian.

\section{B. Pembahasan}

SD Negeri Klampok 01 merupakan Sekolah yang menerapkan pendidikan karakter yaitu dengan penerapan pembiasaan positif yang dilakukan oleh seluruh warga sekolah. Sebagai contoh pembiasaan positif pada anak misal dengan keteladanan. Keteladanan adalah syarat utama keberhasilan pendidikan karakter. Sebagai contoh anak akan sulit untuk belajar disiplin ketika orang tua dan orang dewasa di sekelilingnya tidak pernah menunjukkan kedisiplinan.

Cara menerapkan kedisiplinan yaitu dengan cara pembiasaan. Hal ini sesuai dengan Zakaria dan Arumsari (2018: 23) tentang membangun karakter pada anak bahwa dalam membangun karakter positif pada diri anak adalah dengan melakukan pembiasaan dan pengulangan berbagai perilaku yang baik.

Pola Pembelajaran Pendidikan Karakter Agar Anak Terhindar Dari Kasus Kekerasan Atau Bullying Pada Siswa Kelas V di SD Negeri Klampok 01

Di setiap masyarakat, ada tatanan nilai atau norma yang dianggap baik atau buruk. Selain itu juga ada nilai agama dan budaya yang mendukungnya. Dapat dikatakan bahwa karakter positif adalah sikap dan perilaku baik yang dapat diterima dan sesuai dengan nilai budaya, agama dan norma masyarakat. positif mulai dari siswa sampai di sekolah hingga siswa pulang dari sekolah. Hal ini sesuai dengan Tjahjadarmawan (2017: 104) bahwa pembiasaan sikap disiplin 
mengerjakan PR, tidak terlambat tiba di sekolah, serta budaya 3S (Senyum, Salam, Sapa) merupakan contoh sederhana menanamkan karakter. Begitu juga dengan pendapat kurniawan (2016) tentang baris berbaris di depan kelas Pelaksanaan baris berbaris yang dilaksanakan di kelas dapat menumbuhkan karakter disiplin siswa.

Saat proses KBM (Kegiatan Belajar Mengajar) guru SD Negeri Klampok 01 selalu menanamkan sikap positif pada diri siswa, dari religius maupun hal baik lainnya. Sebelum pelajaran di mulai siswa diharuskan untuk duduk rapi dan doa bersama sesuai kepercayaan masingmasing begitu juga saat jam pelajaran berakhir. Serta membiasakan siswa untuk Shalat Dzuhur berjamaah pada siswa kelas tinggi (4, 5 dan 6) khususnya kelas 6 yang harus sering ikut pelajaran tambahan (les) sebagai persiapan ujian Nasional.

Faktor Pendukung Pola Pembelajaran Pendidikan Karakter Agar Anak Terhindar Dari Kasus Kekerasan Atau Bullying Pada Program Sekolah Ramah Anak Siswa Kelas V di SD Negeri Klampok 01

Keberhasilan tatanan sekolah tergantung dari manajemen sekolah itu sendiri, untuk mengelola sekolah dalam rangka meningkatkan mutu pendidikan berdasarkan kebijakan pendidikan nasional. Setiap sekolah diberikan kebebasan untuk membuat programprogram sesuai dengan kebutuhan sekolah.

Upaya pembentukan karakter yang baik bagi seseorang melalui pembiasaan juga sependapat dengan Lubis (2018: 8) budaya bangsa ini tentu tidak sematamata hanya dilakukan di sekolah melalui serangkaian kegiatan belajar mengajar dan luar sekolah, akan tetapi juga melalui pembiasaan (Habituasi) dalam kehidupan, seperti: religius, jujur, disiplin, toleran, kerja keras, cinta damai, tanggung-jawab, dan sebagainya.

\section{Hubungan Kasus dengan Teori}

Disini peneliti menerapkan karakter yang dimiliki oleh Mega dianggap sebagai kasus dalam penelitian ini karena adanya perbedaan karakter yang dimiliki oleh Mega serta perilakunya saat di kelas memperoleh tanggapan yang berbeda dari teman-temannya. Dari kasus ini teori yang simbolik yang dapat kita temukan adalah konsep diri (I and Me). Dimana "Me" diri sebagai objek,dan "I" ketika sebagai subjek yang bertindak.Konsep Me yang termasuk pada kasus yaitu pada saat Mega terlihat berbeda saat bertemu atau menanggapi seseorang yang lebih tua (Bapak/ibu guru) Dia berkata dengan seolah-olah dirinya tidak bersalah. Sedangkan konsep I muncul pada saat dia berinteraksi bersama temannya dia bersikap egois dan suka marah-marah. konsep I lebih membuka peluang besar bagi kebebasan dan spontanitas.

Menurut adiwikarta dalam Erawati (2013: 47) di simpulkan bahwa interaksionisme simbolik adalah bahwa manusia sebagai individu yang berpikir, berperasaan, memberikan pengertian kepada setiap keadaan, dan melahirkan reaksi dan interpretasi terhadap setiap rangsangan yang dihadirinya.

\section{SIMPULAN}

Setelah dilakukan penelitian mengenai Kajian Tentang Pendidikan Karakter Pada Sekolah Ramah Anak Untuk Siswa Kelas V Studi Kasus di SD 
Negeri Klampok 01. Maka dapat diambil simpulan sebagai berikut : (1) Pola pembelajaran pendidikan karakter agar anak terhindar dari kasus kekerasan atau bullying pada siswa kelas V di SD Negeri Klampok 01 yaitu dengan cara melakukan pembiasaan positif mulai dari siswa sampai di sekolah hingga siswa pulang dari sekolah, begitu pula saat proses KBM (Kegiatan Belajar Mengajar) guru SD Negeri Klampok 01 selalu menanamkan sikap positif pada diri siswa, dari religius maupun hal baik lainnya. Seperti pembiasaan do'a sebelum memulai dan mengakhiri pembelajaran, serta penerapan pendidikan karakter dalam pengintegrasian mata pelajaran guru menanamkan sikap karakter dengan pengintegrasian materi berupa penyampaian butir-butir nilai pancasila yang harus diterapkan pada diri siswa. dengan adanya penerapan hal tersebut diharapkan meminimalisir atau menghilangkan kasus kekerasan atau bullying yang marak terjadi di dunia pendidikan indonesia. (2) Faktor pendukung pola pembelajaran pendidikan karakter di SD Negeri Klampok 01 yaitu adanya penerapan contoh yang baik dari Kepala Sekolah dan Guru beserta jajaran staff SD Negeri Klampok 01. Adanya kesadaran dari seluruh warga sekolah, sehingga lingkungan dapat memberikan rasa aman dan ramah yang akan mengantarkan siswa dalam mengaktualisaikan dirinya pada karakter yang baik, tanpa dihantui perasaan takut, mereka pun akan berani untuk melakukan hal yang benar sehinggga akan terhindar dari kasus kekerasan atau bullying.

Berdasarkan hasil penelitian ditemukan beberapa permasalahan yang belum terpecahkan, sehingga peneliti mengajukan beberapa saran. Saran tersebut antara lain sebagai berikut : (1) Peranan guru sangat dominan dalam membentuk kerakter agar siswa terhindar dari kasus kekerasan atau bullying. Mereka harus dapat menempatkan dirinya sebagai panutan yang dapat memberi contoh yang baik di lingkungan keluarga, lingkungan sekolah, maupun lingkungan masyarakat. (2) Guru lebih mengembangkan strategi pembelajaran yang dapat membuat siswa aktif belajar dan mempraktikkan nilai-nilai karakter yang dikembangkan dalam mata pelajaran. (3) Pendidikan karakter harus didukung semua pihak yang berkepentingan terhadap pendidikan karakter agar dapat mewujudkan generasi yang berkarakter dalam masyarakat, sehingga anak akan jauh dari perilaku yang merusak terutama terhindar dari kasus kekerasan atau bullying.

\section{DAFTAR PUSTAKA}

Daryanto, \& Darmiatun, Suryatri. 2013. Pendidikan Karakter di Sekolah. Yogyakarta: Gava Media.

Erawati, Desei. 2013. Analisis Interaksi Simbolik. Pedagogik Jurnal Pendidikan, Volume 8 Nomer 2, (45-53) Kurniawan, Farida. 2016. Analisis Penerapan Budaya Sekolah Dalam Pembentukan Karakter Disiplin Siswa Di Kelas III Sd N 2 Blunyahan. http://faridakurniawan.blogs.uny.a c.id/wpcontent/uploads/sites/15485/2017/1 0/analisis-penerapan-budayasekolah-dalam-pembentukankarakter-disiplin-siswa-di-kelas-iii- 
sd-n-2-blunyahan.pdf (di unduh pada 20 Oktober 2018)

Indosiar.2017. Kasus Bullying di Thamrin

City Berlanjut Meski Laporan

Dicabut. Jakarta: liputan6. Di akses tanggal 01 april 2018 dari http://www.liputan6.com/news/ $\mathrm{read} / 3027216 /$ kasus-bullying-dithamrin-city-berlanjut-meskilaporan-dicabut

Kurniawan, Farida. 2016. Analisis Penerapan Budaya Sekolah Dalam Pembentukan Karakter Disiplin Siswa Di Kelas III Sd N 2 Blunyahan.

http://faridakurniawan.blogs.uny.a c.id/wp-

content/uploads/sites/15485/2017/1

0/analisis-penerapan-budayasekolah-dalam-pembentukankarakter-disiplin-siswa-di-kelas-iiisd-n-2-blunyahan.pdf (di unduh pada 20 Oktober 2018)

Lubis, Safrida. 2018. Menguatkan Karakter Melalui Pembiasaan. Banda Aceh: Cahaya Bintang Kecil.

Tjahjadarmawan, Elizabeth. 2017. Kumpulan Artikel Pendidikan, Ngopi dulu. Yogyakarta: Deepublish

Zakaria, Mia \& Arumsari, Dewi. 2018. Jeli Membangun Karakter Anak. Jakarta: Bhuana Ilmu Populer. Lubis, Safrida. 2018. Menguatkan Karakter Melalui Pembiasaan. Banda Aceh: Cahaya Bintang Kecil. 